\title{
A Study on the Planning Concept of Elderly Housing in Aged society
}

\author{
고령사회에 대응한 고령자주택의 계획개념에 관한 연구
}

Han, Kyun* 한균 | Kwon, SoonJung** 권순정

\begin{abstract}
Purpose: This basic research tries to provide planning concept of elderly housing which can cope with the needs of the aged society. Methods: This study has been conducted mainly by literature investigation research. Previous researches include Universal and Barrier-Free Design, Elderly Housing Standards, Elderly Welfare Act and other related acts, various papers related to elderly housing, and so on. To set up the Planning concept of elderly housing, elements or indices of previous studies have been comparatively analysed. Results: Elderly housing has been divided into individual type, group type and facility type according to the residents' health and operation system of the housing. This paper focuses on the individual type among three categories. Seven concepts of the elderly housing have been derived as the outcome of this research - Safety, Accessibility, Amenity, Distinguishment, Adaptability, Convenience, and Sociality. Implications: This concept will provide the planning direction on the construction and renovation for Elderly Housing in the future
\end{abstract}

Keywords Elderly housing, Design for the aged, Universal design, Welfare for the aged

주 제 어 고령자주택, 고령자를 위한 디자인, 유니버설디자인, 노인복지

\section{Introduction}

\subsection{Background and Objective}

국가통계포털 (http://www.kosis.kr)을 통한 2010년 65 세 이상 고령자 ${ }^{1)}$ 는 총 인구대비 $11.30 \%(5,424,667$ 명)로 2017년에는 고령인구 비율이 14.01\%(7,118,704명)인 고 령사회 ${ }^{2}$ 로 진입할 것으로 예상된다. 고령인구의 증가와 더 불어 2010년 65세 이상 등록 장애인구는 전체 고령인구의 $17.23 \%$ 로 65 세 미만 인구 대비 등록 장애인비율 $3.72 \%$ 에 비해 높게 나타나며, 2007년 고령 장애인인구는 688,884 명에서 2011년 957,900명으로 늘어났다.

\footnotetext{
* The doctor's course, Department of Architecture, Ajou University (Primary author: ajouhk@gmail.com)

** Vice President, Professor, PhD, Department of Architecture, Ajou University (Corresponding author, sjkwon@ajou.ac.kr)

1) '고령자'와 '노인'은 같은 표현이며, 고령사회에 대한 일반적 인식을 강조하기 위하여 고령자로 통일하여 사용함.

2) UN(1956), "The Aging of population and Its Economic and Social Implication”, 'Population studies' No.26, pp.7 9.에 서 언급된 고령사회는 총 인구 대비 65세 이상 고령자인구비율이 14\% 20\%미만을 말하며 한국은 2000년 7.49\%, 2005년 9.28\%, 2010년 11.30\%로 고령자 인구비율이 급격하게 증가하고 있다.
}

또한, 고령 장애인 인구의 특징을 살펴보면 장애인 등급 6 개 등급을 기준으로 1,2 등급(중증장애)은 줄어들거나 정 체되는 반면 4,5,6등급(경증장애)은 늘어나고 있는 추세이 다 (Figure1).

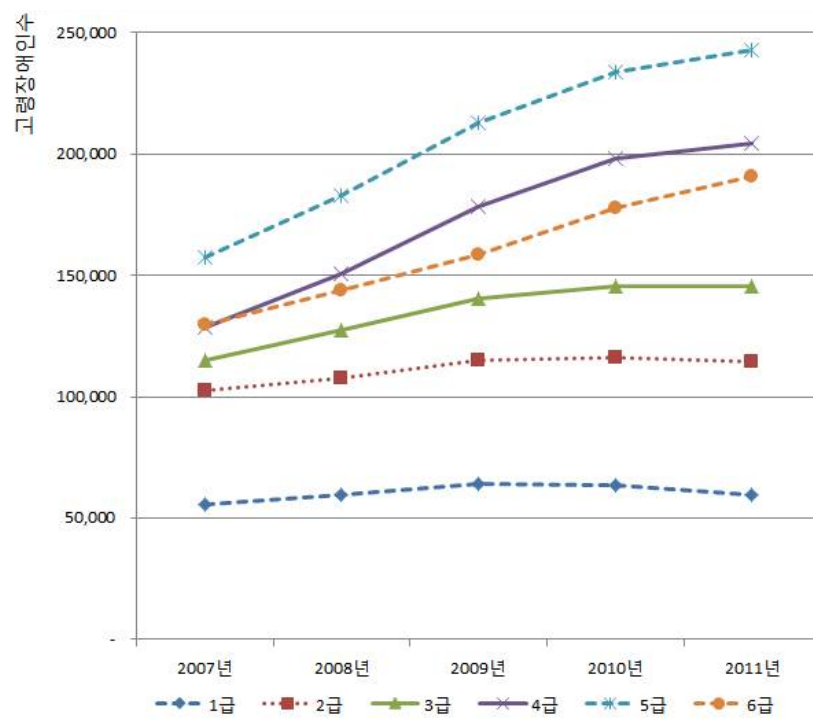

[Figure 1] Trend of the disabled elderly by disability rating (http:// www.kosis.kr) 
이러한 통계는 장래 고령인구증가로 인한 경증장애 고령 자의 수요에 적합한 물리적 환경의 구축 및 복지서비스의 제공이 필요하다는 것을 말해주며, 장애인으로 등록되지 않 은 고령자도 노화에 따라 발생되는 주택사용의 불편사항에 대한 개선요구가 예상된다.

일본의 경우, 과거 고령자에 대한 구빈적 복지 개념으로 '시설에 의한 대응'이 주요 수단이었으나, 막대한 시설 투 자비와 유지비용에 비해 거주하는 고령자의 만족도가 높지 않았기 때문에 다양한 방향으로 고령자를 위한 주거시설 을 공급하다가 현재는 고령자들이 살던 주택이나 지역에서 가능한 자립적인 생활이 가능하도록 대응해 나가고 있다 (Kwon, 2010). 이렇게 자신이 살던 거주지역에서 지속적 으로 거주하는 개념을 'Aging in place'라고 하는데 유엔에 서는 이를 실현하기 위해서 고령자의 능력에 적합도록 살 고 있는 주택을 리모델링 및 개량하도록3) 권고하고 있다.

이러한 세계적인 추세에 입각하여 우리나라도 고령자를 위한 주택의 보급 및 개선을 위한 고령자주택 설계기준들 을 지속적으로 마련하고 있다. 고령자용 주택계획에 참조할 수 있는 현행 제도 및 기준으로 '고령자 배려 주거시설 설 계 치수 원칙 및 기준(KSP1509)'이 현재 국가 표준규격으 로 고지되어 있으며, 보금자리주택건설 등에 관한 특별법 령에 의한 '보금자리주택 업무처리지침'과 주택 개조에 대 한 2007년 '노인가구 주택개조 매뉴얼'이 보급되었다. 그러 나 이러한 기준들은 각 실에 대한 계획기준으로 계획방향 을 위한 근본적인 개념정립은 미흡한 상태이다. 그러므로 본 연구는 고령자주택의 신축 및 개선을 위한 계획요소들 에 대하여 건축적 역할을 규명하고 가능한 중복성을 배제 한 계획개념을 도출하여 고령자주택 계획의 기초자료를 구 축하고 향후 고령자주택의 평가항목으로 활용하고자 한다.

\subsection{Range and Method of Research}

고령자의 특성을 고려한 주택을 고령자용 주택이라고 보 면, 상당히 다양한 건축시설이 존재하기 때문에 본 연구는 입소절차를 통해 사용되는 시설과 구별하여 고령자가 개별 적으로 거주하는 고령자주택의 범위를 분류하여 계획개념 을 도출하였다.

고령자가 거주하는 공동주택 ${ }^{4)}$ 의 신축 및 개선에 관한 계 획요소를 효과적으로 개념화시킴으로써 고령자에게 노말 라이제이션5)이 가능한 환경을 제공하는데 기여하고, 나아

3) 고령화 관련 국제 행동계획과 고령자를 위한 유엔원칙 권고 제19조 및 22조, 2002

4) 공동주택은 단지 및 외부공간, 부대복리시설, 주동공용공간, 단위세 대로 구성되며 공동주택에 관한 연구를 통해 부차적으로 단독주택의 개조에 대한 내용을 포함할 수 있다.

5) 노말라이제이션이란 1959년 덴마크 정신박약협회에 있던 뱅크스 믹 켈이 발표하여 1975년 국제연합 총회에서 권리로 채택된 이념으로 누구나 정상인처럼 살아갈 수 있는 권리를 말한다.
가 'Aging in place'를 실현하는 기초연구를 진행하고자 한 다.

연구의 방법은 먼저 고령자주택 및 유니버설디자인 관련 선행연구의 분석을 통하여 고령자주택 계획요소 및 개념을 도출하고, 각 개념들과 고령자의 신체적, 정신적 특성과의 관련성을 고찰하여 해당되는 계획요소들을 기술함으로써 고령자주택의 계획개념을 구체화시켰다.

\section{Definition of Elderly Housing}

고령자주택이란 일반적으로 고령자의 입주를 전제로, 고 령자의 생활특성을 배려한 건축시설이며, 고령자의 자립적 인 생활을 지원하기 위한 서비스가 복합된 시설로 (박재간, 2002: 31 32) 일반적인 주택의 범위에서 의료복지시설의 범위까지 포괄하는 개념이라고 할 수 있다. 그러므로 고령 자를 위한 시설들에 대한 종류를 알아보고 개별적으로 공 급될 수 있는 고령자주택에 대한 범위를 고찰하였다.

[Table 1]과 같이 노인복지법에서 언급된 시설에 '거주 '의 관점에서 모두 '주택'으로 계획한다면 건축물의 인허가, 이용자의 개별적 · 집합적 특성을 고려한 평면계획, 관리자 의 서비스 등에 대한 건축적인 특성을 간과하여 시설의 효 율성이 떨어지기 때문에 고령자주택을 세분화하여 연구할 필요가 있다.

\subsection{Classification of Elderly Housing}

노인복지법에서 일반적인 주택과 가장 유사한 시설은 노 인주거복지시설 중 노인복지주택이 유일하다. 그러나 동법 에서는 노인복지주택을 노유자시설로 규정하고 인허가 절 차 등은 주택법을 일부 준용하고 있어 건축계획 시 혼란(6) 을 야기하기도 한다. 또한, 최근 노인복지법에서는 노인공 동생활가정, 노인요양공동생활가정의 보급 및 설치가 원활 하도록 건축법상의 단독주택 또는 공동주택에 설치가 가능 하도록 법제화되었다.

[Table 1]은 노인복지시설의 가능한 건축용도를 표기한 표이다. 모든 시설은 기본적으로 건축법상 노유자 시설이 며, 일부 주택용도에 설치가 가능한 시설을 병기하였다. 이 러한 시설들 중 고령자주택은 (Table 2)와 같이 개별형 고 령자주택, 그룹형 고령자주택, 시설형 고령자주택으로 구분 할 수 있다. 개별형 고령자주택은 일반적인 주택의 범위 안 에서 고령자의 특성에 맞도록 미리 계획되거나 개선된 주 택을 말하며 그룹형 고령자주택은 5명이상 9명이하의 입소 자 시설로 노인공동생활가정, 노인요양공동생활가정이 해 당되며, 시설형 고령자주택은 10 인 이상의 입소자 시설인 양로시설, 노인요양시설이 해당된다. 즉, 고령자주택이란

6) 허가 시 협의부서 지정, 건축물의 용도(공동주택 및 노유자 시설)에 따른 주차장 산정기준 등 
고령자의 노화에 대응한 하드웨어적 요소가 제공되는 주택 과 소프트웨어적인 복지서비스를 받는 고령자가 거주하는 시설까지 모두 고령자주택으로 정의한다.

[Table 1] Building uses of Elderly Welfare Facilities

\begin{tabular}{|c|c|c|}
\hline \multicolumn{2}{|c|}{ 노인복지시설(노인복지법) } & 건축용도(건축법) \\
\hline \multirow{3}{*}{$\begin{array}{l}\text { 노인주거 } \\
\text { 복지시설 }\end{array}$} & 양로시설 & $\bullet$ \\
\hline & 노인공동생활가정 & - 혹은 - \\
\hline & 노인복지주택 & $\bullet$ \\
\hline \multirow{2}{*}{$\begin{array}{l}\text { 노인의료 } \\
\text { 복지시설 }\end{array}$} & 노인요양시설 & $\bullet$ \\
\hline & 노인요양공동생활가정 & - 혹은 \\
\hline \multirow{3}{*}{$\begin{array}{l}\text { 노인여가 } \\
\text { 복지시설 }\end{array}$} & 노인복지관 & \multirow{3}{*}{ • } \\
\hline & 경로당 & \\
\hline & 노인교실 & \\
\hline \multirow{5}{*}{$\begin{array}{l}\text { 재가노인 } \\
\text { 복지시설 }\end{array}$} & 방문요양서비스 & \multirow{5}{*}{ - 혹은 - } \\
\hline & 주·야간보호서비스 & \\
\hline & 단기보호서비스 & \\
\hline & 방문 목욕서비스 & \\
\hline & 재가노인지원서비스 & \\
\hline \multirow{2}{*}{$\begin{array}{l}\text { 노인보호 } \\
\text { 전문기관 }\end{array}$} & 중앙노인보호전문기관 & \multirow{2}{*}{$\bullet$} \\
\hline & 지역노인보호전문기관 & \\
\hline
\end{tabular}

Note $\bullet$ : 노유자시설

- : 주택 (단독주택 또는 공동주택)

[Table 2] A Range of Elderly Housing Facilities

\begin{tabular}{|c|c|c|}
\hline \multicolumn{2}{|c|}{ 고령자를 위한 시설 } & 해당시설 \\
\hline \multirow{3}{*}{$\begin{array}{l}\text { 고령자 } \\
\text { 주택 }\end{array}$} & $\begin{array}{c}\text { 개별형 } \\
\text { 고령자주택 }\end{array}$ & $\begin{array}{c}\text { 단독/공동주택* } \\
\text { 노인복지주택 }\end{array}$ \\
\hline & $\begin{array}{c}\text { 그룹형 } \\
\text { 고령자주택 }\end{array}$ & $\begin{array}{c}\text { 노인공동생활가정(노인주거복지시설) } \\
\text { 노인요양공동생활가정(노인의료복지시설) }\end{array}$ \\
\hline & $\begin{array}{c}\text { 시설형 } \\
\text { 고령자주택 }\end{array}$ & $\begin{array}{c}\text { 양로시설(노인주거복지시설) } \\
\text { 노인요양시설(노인의료복지시설) }\end{array}$ \\
\hline \multicolumn{2}{|c|}{ 고령자 서비스 시설 } & $\begin{array}{l}\text { 노인여가복지시설 } \\
\text { 재가노인복지시설 } \\
\text { 노인보호전문기관 }\end{array}$ \\
\hline
\end{tabular}

* 단독/공동주택은 고령자 개인이 주택개조 매뉴얼에 따라 개선된 주택과 고 령자용 보금자리주택 설계기준에 따라 공급되는 공동주택, 재가노인복지서 비스를 받는 고령자 거주 주택, 장애인 - 고령자 등 주거약자 지원에 관한 법률 등에 의해 지원을 받아 개선된 주택을 포함한다.

주택의 사용방식 및 이용자수에 따라 개별형, 그룹형, 시 설형 고령자주택은 계획개념을 각각 구축할 필요가 있다. 일반적 주거형태를 포함하는 개별형 고령자주택과 달리 그 룹형 및 시설형 고령자주택의 계획에서는 일반적인 가족 의 범위를 벗어난 공동생활에 대한 고려가 필요하며, 생활 및 건강과 관련된 서비스를 제공하는 인력을 위한 공간 및 서비스의 효율성 등을 고려한 계획개념이 필요하다. 본 연 구는 개별형 고령자주택 중 공동주택으로 범위로 한정하여
연구를 진행하여 그룹형 및 시설형 고령자주택에서 발생할 수 있는 특수한 계획요소를 제외하였다.

\subsection{Laws and Institutions associated with Elderly Housing}

개별형 고령자주택에 있어서 적용될 수 있는 시설적인 기준7)은 먼저 $\mathrm{KS}$ 표준인 '고령자배려 주거시설 설계치수 원 칙 및 기준 (KSP1509)'과 '노인가구 주택개조 매뉴얼(노 인, 전문가용)', '보금자리주택 업무처리지침의 [별표7,8]', '장애인 · 고령자 등 주거약자 지원에 관한 법률 시행령의 [별표1]'이 있으며, 노인복지법 시행령의 ‘노인주거복지시 설의 시설기준의 [별표2]'가 있다.

이 외에도 '장애인 · 노인 · 임산부등의 편의 증진보장에 관한 법률 시행령 [별표2]'는 설치해야할 편의시설의 종류 를 의무, 권장으로 구분하고 법제화하여 건축물의 인 · 허 가시 반드시 준수해야하며, '장기공공임대주택 입주자 삶의 질 향상 지원법'과 '장애인 고령자등 주거약자 지원에 관한 법률'은 사회적 약자가 거주하는 주택을 개선을 지원할 수 있도록 틀이 마련되어 있다.

고령자를 위한 주택 기준들은 지속적으로 발전되고 있으 며, $\mathrm{KS}$ 기준에 따라 통합되고 있다. 그럼에도 불구하고 이러 한 기준들은 각 실에 대한 규정을 중심으로 기술되고 있으 며, 계획요소들의 근본적인 개념에 대한 정립은 미흡한 상 태이다.

[Table 3] Institutions Associated with Elderly Housing

\begin{tabular}{|c|c|c|}
\hline \begin{tabular}{c|} 
개별형 \\
고령자주택
\end{tabular} & 관련제도 및 기준 & 비고 \\
\hline 공통 & $\begin{array}{l}\text { 장애인 · 노인 · 임산부등의 편의 } \\
\text { 증진보장에 관한 법률 시행령 } \\
\text { [별표2] }\end{array}$ & 보건복지부 \\
\hline \multirow{5}{*}{$\begin{array}{l}\text { 단독/ } \\
\text { 공동주택 }\end{array}$} & $\begin{array}{c}\text { 고령자배려 주거시설 설계치수 원칙 및 } \\
\text { 기준 }(K S P 1509)\end{array}$ & $\begin{array}{l}\text { 산업통상자원부 } \\
\text { 기술표준원 }\end{array}$ \\
\hline & $\begin{array}{c}\text { 노인가구 주택개조 매뉴얼(노인용, } \\
\text { 전문가용) }\end{array}$ & 국토교통부 \\
\hline & $\begin{array}{c}\text { 장기공공임대주택 입주자 삶의 질 향상 } \\
\text { 지원법* }\end{array}$ & 국토교통부 \\
\hline & $\begin{array}{l}\text { 보금자리주택 업무처리지침 † } \\
\text { [별표8] }\end{array}$ & 국토교통부 \\
\hline & $\begin{array}{c}\text { 장애인 고령자 등 주거약자 지원에 관한 } \\
\text { 법률 시행령 [별표1] }\end{array}$ & 국토교통부 \\
\hline \begin{tabular}{c|} 
노인 \\
복지주택
\end{tabular} & $\begin{array}{c}\text { 노인복지법 } \\
\text { 노인복지법 시행규칙 [별표2] }\end{array}$ & 보건복지부 \\
\hline \multicolumn{3}{|c|}{$\begin{array}{l}\text { Note } \\
\text { * 지원법은 시설기준보다는 삶의 질 향상을 위한 주거환경개선 및 주거복지 } \\
\text { 증진에 관한 항목을 포함하고 있다. } \\
\dagger \text { 지침은 기존 고령자용 임대주택시설기준(2006)을 대체한 내용이다. }\end{array}$} \\
\hline
\end{tabular}

7) 물리적 시설계획의 관점에서 본 연구를 진행하기 위하여 재가노인복 지서비스와 관련된 내용은 제외하였다. 


\section{Planning Concepts for Elderly Housing}

\subsection{Literature Survey}

고령자 주거환경 및 주택에 관한 49 개 논문을 분석한 결과, 실거주자 혹은 일반적인 고령자를 대상으로 실태조 사, 만족도조사를 통해 거주자의 요구를 파악하여 건축계 획의 방향을 제시한 연구가 15 건으로 나타났다. 이 가운데 $\operatorname{Lee}(2012)$ 연구와 $\operatorname{Han}(2008)$ 의 연구 내용에는 주거 내 안 전사고 ${ }^{8)}$ 에 있어서 낙상이 가장 고령자에게 미치는 영향이 크고, 욕실, 화장실이 가장 불편한 공간이라고 동일하게 제 시되었다.

설계기준 및 시설표준과 관련된 연구는 11 건이 검토되 었으며, 국내 · 외 설계기준을 비교 · 분석하여 시설의 표 준화를 위한 기초연구의 성격을 갖는다. 이 연구들은 대부 분 고령자의 주택 접근 및 사용을 위한 적정공간의 크기와 활동반경 등을 수치화함으로써 고령자주택 설계의 기초적 인 개념을 제공한다. 'A Study on the Dimensional Standardization of Residential Spaces for the Elderly'(Kim, 2008)가 대표적인 논문이다.

또한, 연구자의 관점에서 국내·외 시설을 직접 조사 하여 시설의 특징을 밝히고 향후 계획요소를 연구한 문헌 은 'A Study on the Type and Planning Characteristic of Residential Facilities for the Elderly in Japan'(Park, 2009)를 포함한 9개의 연구가 조사되었다. 이 외에도 복지 서비스제도와 관련된 연구논문과 전문가조사를 통한 계획 요소의 중요도 평가연구 등이 있다.

위의 연구들에서 고령자 주거환경에 대한 직 · 간접적인 계획요소를 포함하여 이를 정리하고, 이 가운데 고령자주택 에 대한 계획개념을 직접 언급한 논문은 11건으로 [Table 4]와 같다.

선행연구들은 다양한 문헌을 통해 고령자주택의 계획개 념을 도출하였지만, 연구들간의 일관성이 미약9)하며, 용어 상의 기준이 모호하기 때문에 유사한 계획개념을 하나의 개념으로 통합하고, 해당 계획요소의 내용을 하나씩 점검하 여 개념별로 구분하면서 연구를 진행하였다.

\subsection{Planning Concepts and Universal Design}

축약형태의 용어를 알기 쉽게 이해하기 위하여 유니버 셜디자인의 원칙을 활용하여 1 차적으로 계획개념을 도출 하였다. 유니버설디자인은 광의적 의미에서 노말라이제이 션 ${ }^{10)}$ 을 실현하기 위한 개념이다. 선행연구를 통해 유니버 설디자인에서 추구하는 개념을 고찰하여 고령자주택의 계 획개념과 연관성을 살펴보았다. 최근까지 유니버설 디자 인은 Connell (1997)이 제시한 7가지 원칙을 주로 사용하

8) You(2011)의 연구에서는 “본인이 의도하지 않은 사고"를 안전사고 로 정의하였다.
고 있다. 각 원칙의 의미는 주장하는 사람에 따라 다소 다르 게 해석되고 있는 실정이지만, 고령자가 겪는 신체적, 정신 적 변화를 고려하여 유니버설디자인과 유사성을 살펴보면 [Table 5]와 같이 7가지 계획개념으로 도출된다.

[Table 4] Planning Concepts for Elderly Housing

\begin{tabular}{|c|c|}
\hline Literature & Planning Concepts \\
\hline Kim, 2011c & 접근성, 근린차원의 거주성, 경제성, 효율성 \\
\hline Kim, 2011a & $\begin{array}{l}\text { 안전성, 접근성, 감각자극, 개인화, 사회성, } \\
\text { 적응성, 편리성 }\end{array}$ \\
\hline You, 2011 & 안전성, 접근성, 개인화, 사회성 \\
\hline Lee, 2011b & $\begin{array}{l}\text { 안전 및 보안, 실내환경, 문화환경, 가사지원, } \\
\text { 건강 }\end{array}$ \\
\hline Kim, 2011b & $\begin{array}{l}\text { 안전성, 지원성, 쾌적성, 가정적 환경, } \\
\text { 인지효율성, 사회적 환경 }\end{array}$ \\
\hline Lee, 2011a & $\begin{array}{l}\text { 안전성, 접근성, 동작성, 여유공간, 쾌적성, } \\
\text { 안정성, 가변성, 확장성, 편의성, 적응성, 건강성, } \\
\text { 범용성, 규격화, 보편성 }\end{array}$ \\
\hline Ahn, 2011 & $\begin{array}{l}\text { 안전 및 방범, 무장애화, 쾌적성, 사회적 교류, } \\
\text { 건강성, 입지편의성 }\end{array}$ \\
\hline Lee, 2010 & $\begin{array}{l}\text { 안전성, 지원성, 필요공간확보, 쾌적성, 가정적 } \\
\text { 환경, 인지효율성, 사회적 환경, 지원성, } \\
\text { 옥외환경 }\end{array}$ \\
\hline Shin, 2010 & 안전성, 접근성, 쾌적성, 지원성 \\
\hline Kim, 2010 & 안전성, 쾌적성, 거주성, 인지성, 사회성 \\
\hline Bae, 2008 & $\begin{array}{l}\text { 안전성, 접근성, 쾌적성, 친환경성, 친밀성, } \\
\text { 영역성, 향수성, 안정성, 명료성, 공동체성, } \\
\text { 가변성, 지원성, 편의성, 효율성, 단순성, } \\
\text { 관리용이성, 경제성, 연속성, 자립성 }\end{array}$ \\
\hline
\end{tabular}

[Table 5] Planning Concepts and Universal Design

\begin{tabular}{c|l|c}
\hline $\begin{array}{c}\text { 유니버설 디자인의 } \\
\text { 유사 개념 }\end{array}$ & \multicolumn{1}{|c}{ 계획방향 } & $\begin{array}{c}\text { 1차도출 } \\
\text { 계획개념 }\end{array}$ \\
\hline $\begin{array}{c}\text { 오작동에 대한 관용 } \\
\text { (Tolerance for error) }\end{array}$ & $\begin{array}{l}\text { 낙상 혹은 부딪침에 대한 } \\
\text { 건축적 배려 }\end{array}$ & 안전성 \\
\hline $\begin{array}{c}\text { 접근과 사용을 위한 크기와 } \\
\text { 공간 } \\
\text { (Size and Space for } \\
\text { Approach and Use) }\end{array}$ & $\begin{array}{l}\text { 각종 제도 및 기준에 } \\
\text { 나타난 고령자 신체치수를 }\end{array}$ & 고려한 계획 \\
\hline $\begin{array}{c}\text { 인슨석가낭ㅎㅇㅇ한 정보 (Perceptible } \\
\text { Information) }\end{array}$ & $\begin{array}{l}\text { 모호성으로 인한 헷갈림과 } \\
\text { 위험을 쉽게 인지할 수 } \\
\text { 있도록 계획 }\end{array}$ & 인지성 \\
\hline
\end{tabular}

9) 안전성과 접근성, 편리성에 대한 내용은 대부분 연구에서 동일하게 언급되고 있지만, 인지성과 사회성, 적응성, 쾌적성과 같은 개념은 연구자 마다 다소 용어상의 차이를 보이고 있다.

10) 노말라이제이션이란 과거 고령자를 포함한 사회적 약자를 일정 시 설에 격리시켜 보호하는 '수용보호주의'의 기존정책에서, 주거환경 에 익숙한 자신의 지역에서 자립하여 일상생활을 영위할 수 있도록 하는 '지역정주주의'로서의 새로운 정책전환을 의미하는 것이다. 사회적약자도 보통 사람들처럼 생활하고, 함께 살아갈 권리가 있으 며, 그러한 사회야말로 노말하다는 의미이다. (김태일, 2008:176) 


\begin{tabular}{c|l|c}
\hline $\begin{array}{c}\text { 유니버설 디자인의 } \\
\text { 유사 개념 }\end{array}$ & \multicolumn{1}{|c|}{ 계획방향 } & $\begin{array}{c}\text { 1차도출 } \\
\text { 계획개념 }\end{array}$ \\
\hline $\begin{array}{c}\text { 단순하고 직관적인 이용 } \\
\text { (Simple, Intuitive Use) }\end{array}$ & $\begin{array}{l}\text { 이해하기 쉽도록 정보를 } \\
\text { 그래픽으로 표현하거나 } \\
\text { 직관적인 길찾기 계획 }\end{array}$ & 식별성 \\
\hline $\begin{array}{c}\text { 사용상의 융통성 } \\
\text { (Flexibility in Use) }\end{array}$ & $\begin{array}{l}\text { 신체적인 변화, } \\
\text { 가족구성원의 변화에 } \\
\text { 대응가능한 계획 }\end{array}$ & 융통성 \\
\hline $\begin{array}{c}\text { 적은 물리적 노력 } \\
\text { (Low Physical Effort) }\end{array}$ & $\begin{array}{l}\text { 편리한 조작으로 쉽게 } \\
\text { 사용할 수 있는 시설계획 }\end{array}$ & 편리성 \\
\hline $\begin{array}{c}\text { 동등한 사용 } \\
\text { (Equitable Use) }\end{array}$ & $\begin{array}{l}\text { 보통 사람들과 함께 공간을 } \\
\text { 공유하고 사회적 교류와 } \\
\text { 재가서비스를 고려한 계획 }\end{array}$ & 사회성 \\
\hline
\end{tabular}

이러한 유니버설디자인 원칙은 건축보다는 가구나 제품 을 만드는 원칙에 적합하게 사용되었기 때문에, 적절한 실 내환경을 구축하거나 활동성을 고려한 외부환경조성과 같 이 고령자주택에서 추가로 필요한 계획개념을 보완할 필요 가 있다.

\subsection{Derivation of Planning Concept}

[Table 4]의 선행연구에서 제시된 개념들을 살펴보면 총 44 개의 개념적인 용어가 나타난다. 유니버설디자인에서 나 타난 7가지 개념을 기준으로 안전성과 안정성, 사회성과 사 회적 환경, 인지성과 인지효율성 등 유사한 개념과 통합하 면 [Table 6]과 같이 13 개의 2차도출 계획개념이 도출되 고, 이를 다시 종합하여 최종 7 개의 계획개념이 도출되었 다.

먼저 고령자주택에 있어서 안전성은 [Table 4]의 대 부분의 선행연구에서 중요한 계획개념으로 나타났다. $\operatorname{Kim}$ (2011c)의 연구에는 안전성을 구분하고 있지는 않지 만, 접근성에 안전성에 관한 계획요소를 포함 ${ }^{11)}$ 하고 있었 다. 안전성은 고령자의 활동으로 인한 안전사고를 대비한 계획요소가 대부분이다.

접근성은 무장애화와 필요 공간확보를 위한 계획요소를 중점적으로 포함하였다. $\operatorname{Kim}(2011 \mathrm{a})$ 의 경우 접근성에 이 동접근성(접근성)과 공간적 길찾기(식별성)를 포함하였는 데 유니버설디자인의 원칙을 활용하여 접근성과 식별성으 로 분류하여 접근성만의 계획적 성질을 유지하도록 계획요 소를 분류하였다.

쾌적성은 유니버설디자인으로 도출되지 않은 개념으로 고령자의 건강과 실내·외환경의 질적인 요소를 포함하였 다. $\operatorname{Kim}(2011 \mathrm{a})$ 의 연구에서는 감각자극을 계획개념으로 사용하고 있다. 감각자극은 자연채광 및 자연환경요소 활 용, 손잡이 스위치 등이 눈에 잘 보이도록 계획하는 요소를

11) $\operatorname{Kim}(2011 \mathrm{c})$ 의 연구에서 접근성은 장애를 가진 사림이 방문하거 나, 주택 내 안전성을 확보하는 요소라고 정의하였다.
포함하고 있어 자연환경 활용은 쾌적성으로, 명료성을 높이 는 계획은 식별성으로 분류하여 적용하였다.

식별성은 인지성과 명료성을 중심으로 계획요소를 포함 하였다. Kim(2011b), Lee(2010), Kim(2010)의 연구에서 는 인지성 및 인지효율성으로 표현되어 2차도출 계획개념 에서 인지성으로 구분하고 최종도출 계획개념에서 식별성 과 통합하였다. 인지성은 정신적인 노화, 식별성은 감각적 인 노화에 대응하는 개념으로, 노화의 특성상 정신적 - 감 각적 노화가 종합적으로 발생하기 때문에 고령자의 혼란을 방지하고 물리적 상황들을 쉽게 구별해나가고자 하는 성질 을 고려하여 식별성으로 통합하였다.

융통성은 고령자의 가족구성변화, 신체변화에 대응하도 록 가변성, 적응성, 선택가능성을 중심으로 통합된 개념이 다.

편리성은 유니버설디자인의 적은 물리적 노력에 입각하 여 창호의 작동을 편리하게 하는 시설과 지능형 서비스를 활용한 편의시설에 대한 계획요소와 입지적 편리성이 포함 된 개념이다.

사회성은 주거단지 내 커뮤니티 증진을 위한 계획요소와 지역사회와의 연계를 고려한 계획요소를 포함하여 개인과 개인, 개인과 사회와의 연속성을 유지하는 계획개념이다.

연구의 범위에 의하여 개별형 고령자주택을 대상으로 계 획개념을 도출하기 위하여 몇 가지 개념 ${ }^{12)}$ 을 제외하였다. 먼저 타인과의 공동생활에 필요한 '가정과 같은 환경조성' 및 '향수성', '영역성'과 같은 개념을 제외하였고, '관리용이 성', ‘범용성', ‘규격화', '보편성' 및 '경제성'과 유사한 개념 들은 노화에 따른 물리적 대응과 직접적 관련성이 적고 서 비스제공자의 관점에서의 계획요소를 포함하기 때문에 제 외하였다.

지원성, 자립성의 경우 계획요소를 분류하기에 어려움이 있다. 노말라이제이션 즉, 장애를 가진 고령자의 정상적인 생활이 가능하기 위한 모든 계획요소들은 지원성, 자립성과 관련된 개념이 공통적으로 적용된다. 이러한 개념은 계획요 소의 목적성에 부합하기보다 고령자주택의 전반적인 목적 성에 부합하기 때문에 용어사용에서 제외하였으며, 선행연 구에서 지원성에 포함되었던 계획요소들은 접근성, 식별성, 편의성, 융통성 등 해당 계획요소들의 성질에 따라 구분 ${ }^{13)}$ 하였다.

개별형 고령자주택의 계획개념은 최종적으로 유니버설 디자인 원칙에서 인지성을 제외하고, 쾌적성이 추가되어 최 종적으로 7가지 개념으로 도출되었다 (Table 6).

12) 그룹형, 시설형 고령자주택은 대부분의 공간을 공동으로 사용하기 때문에 개인의 영역성확보가 중요한 개념으로 작용한다.

13) $\mathrm{Kim}(2011 \mathrm{~b}$ )은 지원성을 장애가 없는 환경(접근성)에 초점을 맞추 었으며, Shin(2010)은 지원성에 사용자 활동 공간(접근성)과 길찾 기 요소(식별성), 편의성, 융통성을 모두 지원성으로 구분하였다. 
[Table 6] Planning Concepts and Their Implications

\begin{tabular}{|c|c|c|}
\hline $\begin{array}{l}\text { 선행연구에 나타난 } \\
\text { 유사 계획개념 }\end{array}$ & $\begin{array}{l}\text { 2차도출 } \\
\text { 계획개념 }\end{array}$ & $\begin{array}{l}\text { 최종도출 } \\
\text { 계획개념 }\end{array}$ \\
\hline 안전성, 안전 및 방범, 안정성 & 안전성* & 안전성* \\
\hline 여유공간, 동작성, 필요공간확보 & 여유공간 & \multirow{2}{*}{ 접근성* } \\
\hline 접근성, 무장애화 & 접근성* & \\
\hline $\begin{array}{l}\text { 쾌적성, 감각자극, 거주성, 건강성, } \\
\text { 실내환경, 옥외환경, 친환경성 }\end{array}$ & 쾌적성 & 쾌적성 \\
\hline 단순성, 명료성 & 식별성* & \multirow{2}{*}{ 식별성* } \\
\hline 인지성,, 인지효율성 & 인지성* & \\
\hline 가변성, 적응성, 확장성 & 융통성* & 융통성* \\
\hline 편리성, 가사지원, 편의성 & 편리성* & \multirow{2}{*}{ 편리성* } \\
\hline 문화환경, 입지편의성 & 입지성 & \\
\hline $\begin{array}{l}\text { 사회성, 공동체성, 사회적 환경, } \\
\text { 사회적 교류, 연속성, 친밀성 }\end{array}$ & 사회성* & 사회성* \\
\hline 개인화, 가정적환경, 영역성, 향수성 & 개인화 & \multirow{3}{*}{ 제외 } \\
\hline $\begin{array}{l}\text { 효율성, 경제성, 관리용이성, 규격화, } \\
\text { 범용성, 보편성 }\end{array}$ & 효율성 & \\
\hline 지원성, 자립성 & 지원성 & \\
\hline
\end{tabular}

* 유니버설디자인 개념에서 도출된 1 차 계획개념

\subsection{The Relationship between Concept and Aging}

노화는 크게 물리적인 신체기능 저하와 정신기능 저하로 구분된다(Kwon, 2003). 신체적으로는 피부나 뼈가 약해짐 으로서 낙상 시 일반인보다 손상을 많이 받고, 손상이 지속 됨으로서 심리적인 영향까지 나타날 수 있다(Kim,2011a). 또한 노화로 인한 키나 몸무게, 근력의 감소 등으로 신체적 인 활동반경이 작아지고, 감각기관이 약화되어 청력, 시력 에 영향을 미친다. 또한 감각기관의 약화는 2 차적으로 주변 을 인식하는 능력에 영향을 미치며, 위험을 인지하는데 일 반인보다 둔감해진다. 표피면적의 감소는 온도 및 습도변화 에 둔감해져 항상성유지가 어렵게 된다. 정신적으로는 기 억력이 감퇴되고 애매한 그림이나 반복적인 자극에 둔감해 진다.

이러한 신체적 - 정신적 기능저하와 함께 사회 활동력 감 소, 경제활동 감소 및 가족구성원의 변화 등으로 고령자는 고립감을 느끼기도 한다. [Table 7]은 노화 현상과 계획개 념과의 관계를 간략히 나타낸 표이다.

$\mathrm{WHO}$ 에서 장애는 첫째 의학적 관점에서의 신체적 손 상 및 기능상실 장애(Impairment), 둘째, 신체적 손상으 로 인한 능력저하 장애(Disable), 셋째, 기능상실 및 능 력저하로 인한 총체적 장애(Handicap)로 구분하고 있다 (Seong,2003:44). 이러한 장애의 특성과 유사한 노화는 복 합적이고 총체적으로 이루어지기 때문에 고령자가 독립적 인 생활을 영위하기 위한 물리적 · 비물리적 환경을 함께
고려해야한다.

[Table 7] Concept and Aging

\begin{tabular}{|c|c|c|c|c|c|c|c|c|}
\hline \multicolumn{2}{|c|}{ 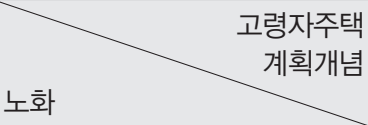 } & $\begin{array}{l}\text { 안 } \\
\text { 전 } \\
\text { 성 }\end{array}$ & $\begin{array}{l}\text { 접 } \\
\text { 근 } \\
\text { 성 }\end{array}$ & $\begin{array}{l}\text { 쾌 } \\
\text { 적 } \\
\text { 선 }\end{array}$ & $\begin{array}{l}\text { 식 } \\
\text { 별 } \\
\text { 성 }\end{array}$ & $\begin{array}{l}\text { 융 } \\
\text { 통 } \\
\text { 성 }\end{array}$ & $\begin{array}{l}\text { 편 } \\
\text { 리 } \\
\text { 성 }\end{array}$ & $\begin{array}{l}\text { 사 } \\
\text { 회 } \\
\text { 성 }\end{array}$ \\
\hline \multirow{5}{*}{$\begin{array}{l}\text { 신체적 } \\
\text { 노화 }\end{array}$} & 피부, 뼈의 약화 & $\bullet$ & 0 & o & & & & \\
\hline & $\begin{array}{c}\text { 근력 약화 / } \\
\text { 보조수단의 사용 }\end{array}$ & 0 & $\bullet$ & & & 0 & • & 0 \\
\hline & 신체치수변화 & 0 & $\bullet$ & & & $\bullet$ & ० & \\
\hline & 생리기능 약화 & 0 & o & O & & O & $\bullet$ & \\
\hline & $\begin{array}{l}\text { 체표면적 감소/ } \\
\text { 감각기관 약화 }\end{array}$ & 0 & 0 & $\bullet$ & • & 0 & $\bullet$ & 0 \\
\hline $\begin{array}{l}\text { 정신적 } \\
\text { 노화 }\end{array}$ & $\begin{array}{c}\text { 기억력/사고력/ } \\
\text { 인지력 감소 }\end{array}$ & 0 & 0 & 0 & • & 0 & 0 & \\
\hline \multirow{2}{*}{$\begin{array}{l}\text { 사회적 } \\
\text { 노화 }\end{array}$} & 사회활동감소 & o & O & O & ○ & & ○ & $\bullet$ \\
\hline & 가족구성원변화 & & & & & $\bullet$ & & $\bullet$ \\
\hline
\end{tabular}

- : 직접적 관련성

○: 간접적 관련성

\section{Planning Concepts and Elements}

\subsection{Range of the Plan in Apartment}

공동주택의 일반적인 계획범위는 단지배치, 옥외(조경) 공간, 부대복리공간, 주동공용공간, 단위세대공간으로 분 류된다. 고령자와 관련된 계획범위별 주요 계획의 목표는 [Table 8]과 같으며, 이를 바탕으로 계획개념들의 주요계 획요소를 분류하였다.

[Table 8] Range of the Plan

\begin{tabular}{|c|c|c|}
\hline \multicolumn{2}{|c|}{ Range of the Plan } & Objectives of the Plan \\
\hline \multirow{2}{*}{ 단지 } & 단지배치 & 편리한 입지 및 쾌적한 단지공간 계획 \\
\hline & 옥외공간 & $\begin{array}{l}\text { 고령자의 건강 및 커뮤니티 증진을 위한 } \\
\text { 옥외공간 계획 }\end{array}$ \\
\hline \multirow{2}{*}{$\begin{array}{l}\text { 공용 } \\
\text { 공간 }\end{array}$} & $\begin{array}{l}\text { 부대복리 } \\
\text { 공간 }\end{array}$ & $\begin{array}{l}\text { 고령자가 사용가능한 부대복리공간의 } \\
\text { 프로그램 및 건축계획 }\end{array}$ \\
\hline & $\begin{array}{l}\text { 주동공용 } \\
\text { 공간 }\end{array}$ & $\begin{array}{l}\text { 고령자의 출입 및 단위세대로 통하는 } \\
\text { 공용공간에 관한 건축계획 }\end{array}$ \\
\hline \multicolumn{2}{|c|}{ 단위세대공간 } & $\begin{array}{l}\text { 단위세대 내 현관, 화장실, 주방 등을 } \\
\text { 중심으로 한 노화에 따른 세부계획 }\end{array}$ \\
\hline
\end{tabular}

\subsection{Planning Elements for Concepts}

1) Safety (안전성)

2011년도 노인실태조사14)에 따르면 65세 이상 고령 자 중 $21 \%$ 가 낙상을 경험하였으며 낙상 후 $72.4 \%$ 가 병원 을 이용하였다. 또한 낙상후유증도 $47.4 \%$ 가 경험하여 낙

14) 2011년도 노인실태조사, 보건복지부, 299쪽 
상으로 인한 사고가 일시적인 장애를 넘어 지속되는 특성 을 보여준다. 낙상의 가장 큰 원인은 바닥이 미끄럽기 때문 (29.8\%)이며, 두번째로 다리에 힘이 풀려서(24.1\%)라고 응답하였다. 즉, 물리적인 재질(환경)과 신체적 근력의 약 화(노화)로 발생되며, 피부 및 골격의 손상이 지속되어 후 유증이 나타나 병원을 자주 이용하게 된다. 안전성은 이러 한 낙상과 직접적으로 관련된 고령자주택의 계획개념이다.

[Table 9] Planning Elements of Safety

\begin{tabular}{|c|c|}
\hline 계획범위 & 주요계획요소 \\
\hline $\begin{array}{l}\text { 단지 } \\
\text { 계획 }\end{array}$ & $\begin{array}{l}\text { 병원 등 의료시설이 가까운 지역의 입지 } \\
\text { 응급상황 시 의료진의 접근 용이성 } \\
\text { 보행안전을 고려한 보차분리 } \\
\text { 경비 및 방범 초소와 CCTV설치 } \\
\text { 보행로 및 외부공간에는 가로공간을 활성화시킬 수 있는 } \\
\text { 계획기법 (자연감시, CEPTED) }\end{array}$ \\
\hline $\begin{array}{l}\text { 공용 } \\
\text { 공간 }\end{array}$ & $\begin{array}{l}\text { 안전성을 고려한 각종 자동문 속도 } \\
\text { 승강기 내부 안전 손잡이 설치 } \\
\text { 복도에 논슬립 등의 미끄럼 방지 바닥재 } \\
\text { 충격을 흡수하는 마감재 사용 } \\
\text { 비상연락시스템 }\end{array}$ \\
\hline $\begin{array}{c}\text { 단위세대 } \\
\text { 공간 }\end{array}$ & $\begin{array}{l}\text { 화장실 바닥 미끄럼 방지 } \\
\text { 벽 또는 가구의 모서리는 둥글게 처리 } \\
\text { 응급상황을 대비한 비상벨 및 동작감지 시스템 } \\
\text { 발코니는 응급상황 발생 시 피난공간으로 활용 } \\
\text { 가스, 가열기구 안전사고 예방을 위한 시설물 설치 }\end{array}$ \\
\hline
\end{tabular}

[Table 9]와 같이 안전성의 주요계획요소는 바닥의 미끄 러움을 방지하고, 돌출부를 최소화하거나 둥근형태로 처리 하는 등 낙상 방지, 충격 완화 계획 등 사고로 인한 신체의 손상을 직접적으로 줄이는 계획요소와 사고의 발견, 사고 자의 호출, 의료진의 접근성에 관한 계획과 같이 사고발생 후 신속한 대응이 가능한 시스템을 포함한다. 또한 승강기 내부에 설치되는 안전 손잡이는 승강기의 움직임에 대비한 안전성의 개념이다.

\section{2) Accessibility (접근성)}

유니버설디자인의 원칙에서 적당한 크기의 공간과 공간 에 대한 접근 및 사용성은 단순히 이동을 위한 접근성을 넘 어 공간을 사용하기에 적합한 활동공간을 확보하는 개념이 다. 신체적 기능이 저하된 고령자에게 있어서 접근성은 일 상생활의 자립성을 확보하며 사회적 활동을 촉진(Kwon, 2003)시키기 때문에 고령자주택의 중요한 개념으로 여겨 지고 있다. KSP1509를 비롯한 제도상의 기준들은 휠체어 나 보행기, 목발 등의 보조기구를 사용하기 위해 단차를 제 거하고 하부공간이 확보되어 휠체어 사용자가 사용가능한 개수대 및 작업대 등을 사용도록 권장하고 있으며 및 문과 복도, 대기공간 등의 크기에 대한 치수적 기준을 제시하고 있다.
[Table 10] Planning Elements of Accessibility

\begin{tabular}{|c|c|}
\hline 계획범위 & 주요계획요소 \\
\hline 단지계획 & $\begin{array}{l}\text { 휠체어 사용 접근성 확보 } \\
\text { 동선상의 단차제거 }\end{array}$ \\
\hline $\begin{array}{l}\text { 공용 } \\
\text { 공간 }\end{array}$ & $\begin{array}{l}\text { 주동에서 고령자가 자주 사용하는 시설(주출입구, 경로당, } \\
\text { 공원, 운동시설, 주차장 등)로의 접근성 확보우선 } \\
\text { 기울기 } 1 / 12 \text { 이하의 경사로 (기울기 } 1 / 18 \text { 권장) } \\
\text { 경사로 참 및 복도 유효폭 } 150 \mathrm{~cm} \text { 이상 확보 } \\
\text { 공간 내 단차 제거 및 연속적인 유도(안전)손잡이 설치 }\end{array}$ \\
\hline $\begin{array}{c}\text { 단위세대 } \\
\text { 공간 }\end{array}$ & $\begin{array}{l}\text { 욕조 높이를 낮게( } 45 \mathrm{~cm}) \text { 하여 원활한 사용성 확보 } \\
\text { 일정한 출입구 폭 및 활동 공간 확보 } \\
\text { 바닥 단차제거 } \\
\text { 휠체어, 의자 등의 사용을 위해 개수대, 작업대 하부 } \\
\text { 깊이확보 } \\
\text { 화장실 사용을 위한 지지(안전)손잡이 설치 }\end{array}$ \\
\hline
\end{tabular}

화장실 내부의 지지(안전)손잡이와 계단과 복도의 유도 (안전)손잡이 등은 접근성의 개념으로 분류하였다. 손잡이 는 대부분 '안전손잡이'라는 명칭을 사용하여 안전성으로 구분하기도 하지만, 휠체어사용자나 중풍 고령자의 경우 손 잡이가 없으면 자립적 사용이 불가능하며, 시각적 장애가 발생할 경우 복도의 손잡이가 없으면 이동(접근)이 어렵기 때문에 접근성으로 분류하였다.

\section{3) Amenity (쾌적성)}

쾌적성은 다른 개념들과 달리 필수적이거나 시설표준에 의해 정의되지 않지만, 최근 들어 삶의 질과 관련되어 고령 자에게 중요한 지표로 여겨지고 있다(Ahn,2011).

쾌적성은 고령자의 항상성을 유지하기 위해 필요한 계획 요소로, 적정 온도 및 습도조절과 관련된 계획요소와 시각 적, 청각적, 후각적 감각기관의 긍정적 자극을 고무시키기 위하여 자연채광과 조망을 적극 고려하고, 소음과 냄새에 대한 차단을 통하여 쾌적한 주거환경을 형성하는 계획요

[Table 11] Planning Elements of Amenity

\begin{tabular}{c|l}
\hline 계획범위 & \multicolumn{1}{|c}{ 주요계획요소 } \\
\hline \multirow{3}{*}{ 단지계획 } & $\begin{array}{l}\text { 자연 및 공원과 인접한 입지 } \\
\text { 주거환경의 쾌적성을 고려하여 남향을 우선시 하는 } \\
\text { 주동배치 } \\
\text { 개인 및 공용정원과 텃밭의 존재 } \\
\text { 단지 내 건강증진을 위한 지압 공간 및 산책로 등 } \\
\text { 운동공간 및 시설의 존재 } \\
\text { 기후변화 등 외부환경(지붕이 있는 회랑형식 보행로 }\end{array}$ \\
$\begin{array}{l}\text { 등)에 대한 배려 } \\
\text { 공용 } \\
\text { 공간 }\end{array}$ & $\begin{array}{l}\text { 출입구는 캐노피를 설치하여 눈비 오는 날에 고령자가 } \\
\text { 불편하지 않도록 계획 }\end{array}$ \\
\hline & $\begin{array}{l}\text { 거주 유닛간 냄새가 나지 않도록 계획 } \\
\text { 소음방지를 위해 흡음, 차음 마감재 사용 } \\
\text { 단위세대 } \\
\text { 공간 }\end{array}$ \\
$\begin{array}{l}\text { 자동온습도 조절장치 } \\
\text { 주거공간 내에서 외부 조망 및 채광이 될 수 있도록 } \\
\text { 창문면적 확보 }\end{array}$ \\
\hline
\end{tabular}


소로 실내환경의 질과 밀접하다(Cho,2010). 또한 자연과 의 근접성, 녹지휴게공간 및 텃밭의 조성 등과 같이 친환경 적 계획요소와 외부활동을 쾌적하게 이용이 가능하도록 그 늘을 제공하거나 악천후에 외부활동을 지원하는 캐노피 및 회랑 계획 등 실외환경의 질과도 관련있다. 이 외에도 쾌적 성은 건강증진을 위한 지압공간, 체육공간 등 건강과 관련 된 활동공간을 제공하는 개념을 포함한다.

\section{4) Distinguishment (식별성)}

안전성이 낙상에 대응한 계획요소라면, 식별성은 다양한 환경정보를 인식하여 자신을 보호하기 위한 모든 계획을 포함한다.

[Table 12] Planning Elements of Distinguishment

\begin{tabular}{|c|c|}
\hline 계획범위 & 주요계획요소 \\
\hline 단지계획 & $\begin{array}{l}\text { 단지 내 현재 위치를 알려주는 안내도 설치 및 위치정보 } \\
\text { 지원 } \\
\text { 보행로는 길찾기(wayfinding)가 용이하도록 계획 }\end{array}$ \\
\hline $\begin{array}{l}\text { 공용 } \\
\text { 공간 }\end{array}$ & $\begin{array}{l}\text { 안내표식은 글자와 그래픽을 동시에 사용하여 눈에 잘 } \\
\text { 띄도록 계획 } \\
\text { 방향 및 위험 등을 주지시키기 위한 점자블록 설치 } \\
\text { 인식 및 접근이 용이한 주출입구 및 계단 } \\
\text { 층별 공간 별 출입문은 쉽게 알아볼 수 있는 마감재와 색 } \\
\text { 사용 }\end{array}$ \\
\hline $\begin{array}{c}\text { 단위세대 } \\
\text { 공간 }\end{array}$ & $\begin{array}{l}\text { 현관 채광창 설치 } \\
\text { 자주 사용하는 동선 상에 바닥 조명 및 야간 센서 설치 } \\
\text { 손잡이, 스위치 및 콘센트는 눈에 잘 띄는 색채와 } \\
\text { 사용하기 좋은 곳에 위치 } \\
\text { 시각 및 청각 겸용 초인종과 화재경보장치 }\end{array}$ \\
\hline
\end{tabular}

고령자는 갑작스런 조도의 변화에 쉽게 적응하지 못하기 때문에 적절한 조도계획이 필요하며, 동일 톤 및 유사 색상 사이의 톤 변별력이 떨어져 색체지각 혼동구간의 색채 배 색은 고령자의 공간사용에 어려움을 초래(Kang,2008)할 수 있으므로 시각적 노화에 대응한 다양한 계획요소가 필 요하다. 또한, 시각을 포함한 감각기관과 정신적 노화가 복 합적으로 나타나 주변환경 및 위험을 인식하는데 많은 어 려움이 있기 때문에 확실한 정보인식을 위한 계획이 필요 하다. 2 가지 이상 감각기관에 대응하는 경고장치(시각, 청 각)와 점자블럭계획(시각, 촉각), 그래픽과 문자를 복합화 한 사인계획 및 색채계획, 공간적인 단순화를 통한 길찾기 계획 등이 식별성의 주요계획요소이다.

\section{5) Adaptability (융통성)}

융통성은 고령자의 다양한 변화요구에 대응 가능한 계획 요소를 포함한다. 노화로 인한 장애는 고령자의 주거이동을 일으키는데, 주거 내 융통성을 부여한다면 'Aging in place' 를 실현시키는데 도움을 줄 수 있다. 미국과 유럽에서는 화 장실에 핸드레일 등이 부착될 것이라 예상되는 곳에 보강
벽체를 미리 설치하고, 장애인 등이 입주 시 필요에 따라 쉽 게 핸드레일이 부착 가능한 주거를 공급한다. 이러한 적응 할 수 있는 주택(Kim, 2011c:59)개념이 융통성의 주요 개 념이다.

융통성은 고령 장애인이 정상적인 가족 구성원과 동거할 경우 더욱 중요하다. 정상적인 구성원과 고령자의 신체적 특징에 모두 적합하도록 조절 가능한 기구나 가구, 실구획 의 변화가능성 및 입주 초기에 선택 가능한 다양한 평면형 식이 융통성의 계획요소에 포함된다.

[Table 13] Planning Elements of Adaptability

\begin{tabular}{|c|c|}
\hline 계획범위 & 주요계획요소 \\
\hline $\begin{array}{c}\text { 단위세대 } \\
\text { 공간 }\end{array}$ & $\begin{array}{l}\text { 다양한 신체치수를 고려한 작업대 및 수납장 설치 } \\
\text { 비디오폰/ 손잡이/ 가스밸브 등 높이 조절 } \\
\text { 높낮이가 조절 가능한 세면대 } \\
\text { 상하이동이 가능한 샤워기 } \\
\text { 세대간 통합 · 분리, 세대내 가변 · 확장 등이 가능하도록 } \\
\text { 가변적 공간구성 } \\
\text { 벽장 내 선반의 높이 조절성 확보 }\end{array}$ \\
\hline
\end{tabular}

광의적으로 융통성은 향후 노화에 따른 대응가능성을 포 함하지만 선행연구 및 기준에서는 이에 대한 내용이 부족 한 실정이다. 다만 신체적 변화에 대응한 기구 및 가구의 조 절과 관련된 내용이 [Table 13]과 같이 계획요소로 나타났 다.

\section{6) Convenience (편리성)}

편리성은 고령자가 적은 물리적 노력으로 쉽게 사용할 수 있는 공간계획과 설비계획, 긴 이동 및 대기를 필요로 할 경우 휴식 공간 및 시설을 제공하는 것이다. 편리성의 계획 요소들은 필수적인 요소로 여겨지지 않을 수 있지만, 고령 자는 근력의 감소 및 지구력의 감소로 일상적인 생활과 관 련된 운동도 쉽게 피곤하고 무리할 경우 사고로 연결될 수 있다.

실내의 경우, 자주 사용하는 공간과 공간사이의 동선이 길거나, 굴곡진 동선을 피해야하며, 실내 청소가 용이한 마 감재를 통해 보다 신속하고 편리하게 청소를 마칠 수 있도 록 배려하는 계획요소와 문 및 창의 여닫음과 수도꼭지 조 절 등에 어려움을 겪기 때문에 쉽게 작동시킬 수 있는 다양 한 기구 및 설비 시스템 계획이 필요하다. 또한 외부활동 이 후 지속된 운동에 대한 휴식을 제공할 필요가 있기 때문에 승강기 내부 및 대기공간에 휴게의자를 설치하고, 긴 복도 의 경우에는 알코브형 휴식공간을 제공하여 편의를 증진시 킬 수 있다.

최근에는 고령자들의 문화 및 여가생활과 관련된 교통 적 입지 편리성도 중요하게 여겨지고 있으며 (Bae,2008), 지능형 주택서비스에 해당하는 고령자 활동 모니터링, 원 버튼 자동 점소등, 원격건강관리시스템, 홈씨어터 등 (Lee, 
2011b)이 공급되어 고령자의 다양한 수요에 대응할 것으 로 기대된다.

[Table 14] Planning Elements of Convenience

\begin{tabular}{|c|c|}
\hline 계획범위 & 주요계획요소 \\
\hline 단지계획 & 교통이 편리한 입지계획 \\
\hline $\begin{array}{l}\text { 공용 } \\
\text { 공간 }\end{array}$ & $\begin{array}{l}\text { 승강기와 연결된 층별 부대시설 프로그램 계획 } \\
\text { 주동입구 슬리이딩 자동문 설치 } \\
\text { 승강기 대기를 위한 의자설치 } \\
\text { 긴 복도일 경우 알코브형 휴게공간 설치 }\end{array}$ \\
\hline $\begin{array}{c}\text { 단위세대 } \\
\text { 공간 }\end{array}$ & $\begin{array}{l}\text { 현관 안전 손잡이 및 접이식 의자 설치 } \\
\text { 출입문과 수납장의 문은 미닫이문 설치 권장 } \\
\text { 문, 창문, 손잡이, 각종스위치, 수도꼭지 등 조작편의성 } \\
\text { 증진 } \\
\text { 기기 등의 작동 편의를 위한 리모콘 스위치 } \\
\text { 목욕 시 걸터앉을 수 있는 간이의자 설치 } \\
\text { 청소가 용이한 마감재 사용 }\end{array}$ \\
\hline
\end{tabular}

7) Sociality (사회성)

사회성은 공동주택 형태의 고령자주택에서 더욱 중요한 요소로 작용되는 개념이다. 이미 '주택건설기준 등에 관한 규정'에 있어서 100세대 이상 공동주택에는 경로당의 설치 가 의무화되었고, '보금자리주택 업무처리지침'에는 일반단 지에 고령자주택의 공급을 통한 사회적 혼합과 더불어 사 회적 기업을 위한 공간 ${ }^{15)}$ 설치가 지침화되었다.

[Table 15] Planning Elements of Sociality

\begin{tabular}{|c|c|}
\hline 계획범위 & 주요계획요소 \\
\hline 단지계획 & $\begin{array}{l}\text { 가족, 친구 등 친분관계를 유지할 수 있는 지역에 입지 } \\
\text { 공동으로 즐길 수 있는 휴게공간 및 운동시설 } \\
\text { 공동텃밭 등 여가활동 공간 조성 }\end{array}$ \\
\hline $\begin{array}{l}\text { 공용 } \\
\text { 공간 }\end{array}$ & $\begin{array}{l}\text { 경로당, 노인정의 설치 및 타 시설과의 복합화 } \\
\text { 고령자의 공동 이용이 가능한 다목적실 } \\
\text { 외부기관, 단체 등의 도움을 위한 자원 봉사실 및 사회 } \\
\text { 봉사지원 계획 (상담, 식사지원, 의료지원) } \\
\text { 소규모 커뮤니티 및 비공식적 커뮤니티 활성화를 위한 } \\
\text { 공용공간 설치 ( } 1 \text { 층 필로티 공간 활용) } \\
\text { 하나의 주동 내 세대 혼합 }\end{array}$ \\
\hline
\end{tabular}

사회성의 주요계획요소는 사회적관계가 유지될 수 있는 지역의 입지성, 공동 활동이 가능한 외부공간계획과 부대시 설계획, 다양한 세대와의 혼합계획 등이다. 또한, 노후 공동 주택에서도 주민들과의 커뮤니티공간을 제공함으로써 외 부활동이 늘어나고 주민간의 대화시간이 늘어나는 등 사회 적 관계에 긍정적 효과(Lim:2010)를 기대할 수 있어 신축 시설 뿐만 아니라 노후 공동주택의 개선 시에도 사회성을

15) 보금자리주택내 사회적 기업을 마련할 수 있도록 규정되어 영구임 대주택의 경우 500세대 이상인 단지에는 사회적기업의 입주공간을 $100 \mathrm{~m}^{2}$ 이상 설치하도록 규정하고 있다. (보금자리주택 업무처리지 침 제34조의 6)
고려할 필요가 있다.

\section{Conclusion}

고령인구 및 고령장애인구 증가에 따라 다양한 건축물 에 대한 요구가 증대될 것으로 예상된다. 노인복지법에 따 른 다양한 시설들을 개별형, 그룹형, 시설형 고령자주택으 로 구분하였다. 개인 소유가 가능한 점에서 개별형 고령자 주택에는 일반적인 주택과 노인복지주택이 있으며, 시설형 고령자주택은 10 인 이상이 입소를 통해 이루어지는 양로시 설과 노인요양시설이 있다. 최근에는 개별형과 시설형 사이 에 그룹형 고령자주택이 등장하였는데 여기에는 노인공동 생활가정과 노인요양공동생활가정이 해당된다. 그룹형 고 령자주택은 기존의 일반적인 단독 - 공동주택에도 설치 될 수 있는 제도적 틀이 마련되어 향후 복지시설과 주택시설 의 복합형태가 가능하다.

'Aging in Place'의 관점에서 개별형 고령자주택의 공급 및 기존 주택의 개선을 통해 시설형 고령자주택으로의 입 소를 최대한 지연시키고 거주자의 자립적인 생활기간을 연 장시킬 필요가 있다. 이를 위해 선행연구 및 유니버설디자 인 원칙 등을 토대로 개별형 고령자주택 건축 시 고려해야 할 가지 건축개념을 도출하였다.

첫째, 안전성은 낙상으로부터 고령자의 피부나 뼈 등의 손상을 최소화하기 위한 물리적 계획과 사고 발생 시 신속 한 대응이 가능한 시스템이 포함된다. 둘째, 접근성은 신체 적인 노화에 따른 이동성을 고려한 물리적 장애의 제거와, 사용성을 고려한 공간의 크기를 주요 계획요소로 포함하였 다. 셋째, 쾌적성은 고령자의 항상성 유지를 위한 계획요소 와, 자연 및 건강과 관련된 외부 공간의 계획요소를 포함하 였다. 넷째, 식별성은 노화에 따른 시각, 청각적 장애로 인 한 위험지각을 높이는 계획요소와, 노화에 대응한 공간적 인 길찾기, 색상구분 등을 통하여 명료성을 높이는 계획요 소를 포함하였다. 다섯째, 융통성은 변화가능성을 내포한 건축계획과, 가족구성원과 함께 거주할 수 있도록 조절가능 하고 선택 가능한 계획요소들이 포함된다. 여섯째, 편리성 은 적은 물리적 노력으로 쉽게 시설의 사용이 가능하도록 효율적 동선계획, 조작성 향상계획과 스마트 홈과 관련된 계획요소가 포함된다. 마지막으로 사회성은 고령자가 사회 적 서비스를 원활히 접할 수 있고 이웃과 동등하게 삶을 영 위하기 위한 계획요소를 포함한다.

도출된 개념들은 일부 상호보완적인 관계를 가질 수 있 으나 근본적으로 노화에 대응하되, 계획개념이 최대한 중복 되지 않도록 고려하였다. 예를 들어 현관의 손잡이의 경우, 신발을 신는 과정에서 넘어지지 않도록 고려한다면 안전성 의 개념이 강하며, 현관을 통해 이동을 원활히 하는 점을 고 려한다면 접근성의 개념에 해당될 수 있다. 그러나 본 연구 
에서는 좀 더 적은 물리적 노력으로 현관을 사용할 수 있다 는 취지에서 현관 손잡이의 설치를 편리성의 개념으로 구 분하였다. 계획요소들은 최대한 1차적인 목적을 고려하여 각 개념에 해당하는 계획요소로 분류하였다.

연구의 한계와 그에 따른 후속연구로는 먼저, 본 연구는 개별형 고령자주택 개념을 도출하였기 때문에 최근 제도화 된 그룹형 고령자주택의 개념을 고찰하여 개별형과 시설형 고령자주택과의 관계설정과 바람직한 보급을 위한 연구가 필요하다. 둘째 개별형 고령자 주택의 7가지 계획개념이 실 제 고령자의 일상생활적인 측면에서 얼마만큼 도움이 되는 가에 대한 검증이 이루어지지 않아, 계획개념에 따른 계획 요소들의 실효성 검증연구가 필요하다. 셋째, 선행연구 중 심의 연구진행으로 새롭게 고안되거나 도출된 계획요소가 부족하기 때문에 계획개념마다의 다양한 계획요소를 고안 하고 나아가 평가요소로 발전시킬 수 있는 연구가 필요하 다.

본 연구는 위와 같은 후속연구의 필요성을 제기하고, 고 령자주택의 계획 시 최소기준을 만족시키기 위한 건축계획 을 벗어나 고령자를 위한 풍부한 건축 환경이 조성될 수 있 는 기초자료를 제공하는데 의의가 있다.

Acknowledgements: This research was supported by Basic Science Research Program through the National Research Foundation of Korea(NRF) funded by the Ministry of Education, Science and Technology (Grant Number : 2012R1A1A2044496)

\section{References}

1. Ahn, Jun Young; Oh, Dong Hoon, 2011, “A Study on Characteristics of Residential Environment in Elderly Housing : Focusing on the urban elderly housing in Seoul”, Housing studies review Volume 19, No.3 (2011.8) pp.171-193

2. Bae, Jeung Yun; Kang, Kyung Yeon; Lee, Kyung Hoon, 2008, "A Study on the Planning of National Rental Housing for Elderly in the Aged Society", Journal of Architectural Institute of Korea Volume 24, No.5 (2008.5) pp.23-30

3. Bettye Rose Connell, Mike Jones, Ron Mace, Jim Mueller, Abir Mullick, Elaine Ostroff, Jon Sanford, Ed Steinfeld, Molly Story, and Gregg Vanderheiden, 1997, THE PRINCIPLES OF UNIVERSAL DESIGN, NC State University, The Center for Universal Design

4. Cho, Sung Heui; Kang, Nana; Jun, Eun-Jung, 2010, "The Elderly's Perspectives on Apartments as a Healthy Home Environments" Journal of korea Ecological Environment Architectural Institute v.10 n.6 pp.81-89,

5. Han, Pil Won; Sohn, Myung Gi; Kim, Hong Yong; Park, Jin
Ock, 2008, "A Study on the Planning Elements for the Elderly in Remodeling the Permanent Rental Apartment - Based on the Analysis of the Requirements of the Elderly at Daejeon Bora Apartment Site 1", Journal of Architectural Institute of Korea Volume 23 No. 12 (2007.12) pp.73-82

6. Kang, Kyung Yeon; Bae, Jeung Yun; Lee Kyung Hoon, 2008, "A Study on the Color Scheme for the Elderly in Apartment Bathroom", Journal of Architectural Institute of Korea Volume 24, No. 3 (2008.3) pp.125-132

7. Kim, Dae Jin; Lee, Jae Hwa; Ha, Mi Kyoung, 2010, "Planning for Healing Environment through Evidence-based Design Foucing on Geriatric Hospital -", Journal of korea Ecological Environment Architectural Institute Fall Conference Volume 10, No.2 (2010)

8. Kim, Dae Jin; Shin, Hye Kyeong; Ryu, Ho Sik, 2011a, “The Evaluation of Planning Elements in the Senior Housing Environment based on Characteristics of Elderly", Journal of Architectural Institute of Korea Volume 27, No.9 (2011.9) pp. 151-160

9. Kim, Kot Song I; Whang, Hee Joon, 2011b, "A Study on the Correlation Analysis Between Site Planning Factors of The National Rental Apartment and Residential Satisfaction of the Elderly", Journal of Architectural Institute of Korea Volume 27, No.12 (2011.12) pp.71-82

10. Kim, Min Gyeong; Nam, Youn ok, 2011c, "Planning Factor of the Housing for the Disabled and Aged based on the Inclusive Housing", Journal of the Korea Institute of Healthcare Architecture Volume 17 No.4 (2011) pp.57-68

11. Kim, Seok jun; Kwon, Soon Jung; Oh, Eun Jin; Kim, Noh Seok; Kim, Sang Gil; Lee,Teuk Koon, 2008, "A Study on the Dimensional Standardization of Residential spaces for the Elderly", Journal of the Korea Institute of Healthcare Architecture Volume 14, No3 (2008. 8) pp.3-11

12. Kwon, Soon Jung, 2003, "Characteristics of Older People and the Design of Elderly Care Facilities”, Journal of Architectural Institute of Korea Volume 47, No.6 (2003.06) pp.25-29

13. Kwon, Soon Jung, 2010, "A Study on the Types and Supply of Elderly Housing in Japan”, Journal of the Korea Institute of Healthcare Architecture Volume 16 No3 pp.49-56

14. Lee, Ho Sung, 2012, "Residence Consciousness of The Elderly Residing in Apartments”, Journal of the Korea Institute of Healthcare Architecture v.18 n.1 pp.25-34

15. Lee, Ho Sung, 2011a,"A Study on the Unit Plan Criteria for an Aging Friendly Apartment House”, University of Seoul graduate school

16. Lee, Hung Su, 2008, "A Study on the Measures to Expand 
Aged-Friendly Housing Facilities through the Remodeling of Permanent Leased Apartment”, University of Seoul graduate school. (2008.8)

17. Lee, Hyun soo; Park, Sung Jun; Jung Hyun Won; Lee, Min A, 2011b, "A Study on a Correlation Between Senior Lifestyle and Intelligent Home Service", Journal of Architectural Institute of Korea Volume 27, No.6 (2011. 6) pp.131-141

18. Lee, Jeong Nam, 2010, "The Study on the Critical Planning Factors that Influence on the Residents' Satisfaction in the Residential Facilities for the Elderly", Journal of Architectural Institute of Korea Volume 26, No.3 (2010.3) pp.41-48

19. Lim, Eui sun; Lee, Yeun Sook; Kim, Ju Suck, 2010, 'The Effect of Socio-Physical Regeneration on Social Network of Elderly Residents - Focused on Hanmaum public apartment of Daejeon implemented under Rainbow project, Journal of korea Ecological Environment Architectural Institute v.10 n.5 pp.31-41

20. Park, Jin Sook, Lee, moon sup, 2009 "A Study on the Type and Planning Characteristic of Residential Facilities for the Elderly in Japan - Focused on the Residential Facilities for the Elderly in the Suburbs of Tokyo" Journal of Architectural Institute of Korea Volume 25, No.10 (2009. 10) pp.39-46

21. Seong, Ki Chang; Chai, Choul-Gyun; 2003 " A Study on the Concept on Architectural Planning in Consideration of People with disabilities”, Journal of the Korea Institute of Healthcare Architecture Volume 9 No. 2 (2003.9) pp.43-50

22. Shin, Hwa Kyoung; Lee, Joon Min, 2010, "A Study on the Evaluation for Elderly Housing Environment - Countent Analysis of Elderly Housing Environment Literature Issued after 2000-",Journal of Korea Housing Association Volume 21, No.1 (2010.2) pp.151-159

23. You, Jong Ok; Park, Jae Seung, 2011, “A Study on Proposal of Facility Standard by Research of Safety Accidents at Elderly Housing Welfare Facility", Journal of the Korea Institute of Healthcare Architecture Volume 17 No. 43 (2011.03) pp.7-16

24. 김태일 2008, "노말라이제이션의 이념 실천을 위한 고령화 사회”, 보고사

25. 박재간, 2002, “노인전용주거시설의 개발전략", 아시아미디어리서 치 